\title{
Interaction of Vibrio cholerae non-01/non-O139 with Copepods, Cladocerans and Competing Bacteria in the Large Alkaline Lake Neusiedler See, Austria
}

\author{
Alexander K. T. Kirschner • Sonja Schauer • Birgit Steinberger • Inés Wilhartitz • \\ Christopher J. Grim • Anwar Huq • Rita R. Colwell • Alois Herzig • Regina Sommer
}

Received: 14 June 2010 /Accepted: 16 October 2010 / Published online: 4 November 2010

(C) The Author(s) 2010. This article is published with open access at Springerlink.com

\begin{abstract}
Vibrio cholerae is a human pathogen and natural inhabitant of aquatic environments. Serogroups O1/O139 have been associated with epidemic cholera, while non-O1/nonO139 serogroups usually cause human disease other than classical cholera. $V$. cholerae non-O1/non-O139 from the Neusiedler See, a large Central European lake, have caused ear and wound infections, including one case of fatal septicaemia. Recent investigations demonstrated rapid planktonic growth of $V$. cholerae non-O1/non-O139 and correlation with zooplankton biomass. The aim of this study was to elucidate the interaction of autochthonous $V$. cholerae with two dominant crustacean zooplankton species in the lake and investigate the influence of the natural bacterial community on this interaction. An existing data set was evaluated for statistical relationships between
\end{abstract}

Electronic supplementary material The online version of this article (doi:10.1007/s00248-010-9764-9) contains supplementary material, which is available to authorized users.

A. K. T. Kirschner $(\bowtie) \cdot S$. Schauer $\cdot$ B. Steinberger $\cdot$ R. Sommer Institute for Hygiene and Applied Immunology, Water Hygiene, Medical University of Vienna,

Kinderspitalgasse 15,

Wien 1095, Austria

e-mail: alexander.kirschner@meduniwien.ac.at

\section{Wilhartitz}

Institute of Chemical Engineering, Research Group

Environmental Microbiology and Molecular Ecology,

Vienna University of Technology,

1060 Vienna, Austria

C. J. Grim · A. Huq • R. R. Colwell

University of Maryland Institute for Advanced Computer Studies,

University of Maryland,

College Park, MD, USA zooplankton species and $V$. cholerae and co-culture experiments were performed in the laboratory. A new fluorescence in situ hybridisation protocol was applied for quantification of $V$. cholerae non-O1/non-O139 cells, which significantly reduced analysis time. The experiments clearly demonstrated a significant relationship of autochthonous $V$. cholerae non-O1/non-O139 with cladocerans by promoting growth of $V$. cholerae non-O1/non-O139 in the water and on the surfaces of the cladocerans. In contrast, copepods had a negative effect on the growth of $V$. cholerae non-O1/ non-O139 via competing bacteria from their surfaces. Thus, beside other known factors, biofilm formation by $V$. cholerae on crustacean zooplankton appears to be zooplankton taxon specific and may be controlled by the natural bacterial community.

R. R. Colwell

Center for Bioinformatics and Computational Biology,

University of Maryland,

College Park, MD, USA

\author{
A. Herzig \\ Biological Research Institute Burgenland, \\ 7142 Illmitz, Austria
}

Present Address:

I. Wilhartitz

Department Environmental Microbiology, EAWAG,

Dübendorf, Switzerland 


\section{Introduction}

Vibrio cholerae is both a human pathogen and a natural inhabitant of aquatic environments [1-3]. V. cholerae serogroups 01 and 0139 have been shown to be associated with epidemic cholera, while $V$. cholerae non-O1/non-O139 serogroups sometimes cause disease other than epidemic cholera. Less severe watery diarrhoea, wound infections, blood-stream infections or ear infections have frequently been reported $[4,5]$. $V$. cholerae $\mathrm{O} 1 / \mathrm{O} 139$ usually live in association with crustacean zooplankton, mainly copepods, where they build biofilms on external and internal surfaces [6-8]. It has been hypothesised that attachment to surfaces serves as a survival strategy of $V$. cholerae to escape from heterotrophic nanoflagellate grazing [9]. Due to its ability to degrade chitin, these surfaces are also used as a nutrient source $[10,11]$. Moreover, chitin has been shown to induce DNA uptake by $V$. cholerae $[12,13]$ enhancing the environmental fitness of this bacterium.

In contrast to the vast knowledge of the ecology of $V$. cholerae O1/O139, much less is known about the environmental behaviour of $V$. cholerae non-O1/non-O139 strains. In Austria, V. cholerae non-O1/non-O139 has caused several ear and wound infections in recent years [14]. Most of these cases, including a lethal septicaemia, were explicitly linked to recreational activities in the Neusiedler See, a large shallow lake in Central Europe. A recent study also demonstrated the permanent autochthonous existence of $V$. cholerae non-O1/ non-O139 strains in this moderately saline, alkaline lake [15].

Over a period of 4 years, a significant correlation of the relative frequency of $V$. cholerae positive samples with total zooplankton biomass was reported [15]. The aim of the present investigation was to elucidate the association of autochthonous $V$. cholerae and a 'foreign' $V$. cholerae nonO1/non-O139 strain with the two dominant crustacean zooplankton species of the open water area of the Neusiedler See. Arctodiaptomus spinosus is the dominant copepod and Diaphanosoma mongolianum is the dominant cladoceran. The 4-year data set accumulated by our laboratory was reevaluated to determine statistically significant relationships between the two dominant zooplankton species and $V$. cholerae. Laboratory microcosm co-culture experiments were performed to study interaction of $V$. cholerae with $A$. spinosus and D. mongolianum. Batch cultures were prepared with filter sterilised and $2-\mu \mathrm{m}$ filtered lake water to determine the influence of the natural bacterial community on the association of $V$. cholerae with zooplankton.

Our results showed that $V$. cholerae non-O1/non-O139 strains minimally attached to copepods in the lake but much more frequently to cladocerans. The competing natural bacterial community was found to have a significant negative influence on the growth of planktonic $V$. cholerae non-O1/non-O139.

\section{Materials and Methods}

\section{Study Site and Sampling}

The lake Neusiedler See is the largest shallow alkaline lake in central Europe (surface area $321 \mathrm{~km}^{2}$; maximum depth $1.8 \mathrm{~m}$; mean depth $1.1 \mathrm{~m}$; $\mathrm{pH} 8.5$ to 9.1 , salinity: $1-2 \mathrm{~g}$ $\mathrm{L}^{-1}$ ). About $55 \%$ of the lake is covered with reeds. Due to the shallow water column, water temperature changes rapidly in response to weather events and frequent resuspension of sediment caused by winds and currents results in a high concentration of suspended solids in the water column $[15,16]$. During the period from 2001 to 2004, at five sampling stations, lake water samples were collected and tested for the presence of culturable $V$. cholerae at weekly to biweekly intervals from April to October and at longer intervals (4 to 8 weeks) from November to March. Concomitantly, samples for crustacean zooplankton abundance and a variety of environmental variables were taken, as described in detail in Kirschner et al. [15]. Data from those investigations were re-evaluated for statistical relationships between the abundance of the two dominating zooplankton species (A. spinosus and D. mongolianum) and $V$. cholerae prevalence.

For laboratory growth experiments, water samples were collected in clean 10-L canisters from sampling site 5, a station representative for the centre of the lake (Supporting Information: Fig. S1), during different seasons between June 2007 and September 2008. Zooplankton samples were collected with vertical net hauls (mesh size, $250 \mu \mathrm{m}$ ) resulting in integrated samples of the entire water column. Depending on water depth at the respective station (between 75 and $180 \mathrm{~cm}$ ), 50 to $120 \mathrm{~L}$ of lake water was filtered. Zooplankton was collected from the net and placed into sterile $200-\mathrm{ml}$ glass bottles. All samples were transferred to the laboratory at in situ temperature in an isolated box in the dark within $1.5 \mathrm{~h}$. Copepods (A. spinosus) and cladocerans (D. mongolianum) were separated in Petri dishes under a stereoscopic microscope (MBS 10, USSR) at $\times 20$ magnification after careful rinsing with sterile filtered lake water (NSW, see below). Extreme care was taken to avoid damage to the animals and only active individuals in all development stages (nauplii to adults) and both sexes (females with egg masses) were collected for the experiments. In contrast to other studies where zooplankton was from laboratory stock cultures [e.g. 25], we designed our experiments to reflect the natural environment as closely as possible by using freshly collected zooplankton. This was considered to reduce bias in the experimental design. On the other hand, zooplankton freshly collected from the lake are colonised by $V$. cholerae, as was observed during the experiments. However, the number of $V$. cholerae on freshly collected individuals was in all cases 
less than 500 cells per individual and thus less than $1 \%$ of the $V$. cholerae non-O1/non-O139 cells added, imposing a small effect on the results.

\section{Design of Growth Experiments}

Batch growth cultures with different concentrations of copepods and cladocerans were prepared in sterile 1-L glass flasks. A volume of $800 \mathrm{ml}$ was chosen, because smaller volumes increase the probability of the 'bottle effect' [17], leading to overestimation of bacterial growth. For each experiment, 150, 50 and 0 (control) freshly collected zooplankton were added to separate flasks. Flasks were filled either with freshly collected sterile filtered ('without initial competition') or with $2-\mu \mathrm{m}$ filtered ('with competition') lake Neusiedler See water (NSW). Sterile filtered NSW was produced via prefiltration through a clean $10-\mu \mathrm{m}$ plankton net, followed by filtration through $0.2-\mu \mathrm{m}$ cellulose acetate filters (Whatman, Dassel, Germany) and through $0.1-\mu \mathrm{m}$ Anodisc aluminium oxide filters (Whatman). Filtration through a $2-\mu \mathrm{m}$ polycarbonate filter (Whatman) resulted in the effective elimination of potential protozoan grazers [17], while the natural bacterial community was still present in large numbers. In sum, six flasks were prepared for each experiment, which was repeated three times at three different temperatures for copepods and cladocerans, respectively. For inoculation, $V$. cholerae strain non-O1/non-O139 (Vc070521H5) isolated from lake Neusiedler See in the beginning of the experimental series following the protocol of Kirschner et al. [15] was thawed from a frozen $\left(-80^{\circ} \mathrm{C}\right)$ stock and cultured overnight in liquid Luria-Bertani (LB) medium at $37^{\circ} \mathrm{C}$. An aliquot $(100 \mu \mathrm{l})$ was transferred to $50 \mathrm{ml} \mathrm{LB}$ broth and grown on a rotary shaker until an optical density at $620 \mathrm{~nm}$ of 0.6 to 0.8 was reached $(1.5$ to $3 \mathrm{~h})$. Aliquots were centrifuged $(7,500 \times g, 10 \mathrm{~min})$ and washed three times with sterile filtered autoclaved lake water. The washed pellet was resuspended in $10 \mathrm{ml}$ of sterile lake water and stored at the respective in situ temperature until the beginning of the experiment (approximately $4 \mathrm{~h}$ ) to allow adaptation to the environmental conditions. An aliquot $(5$ to $10 \mu \mathrm{l})$ was inoculated into the flasks to yield a final concentration of $0.8 \times 10^{4}$ to $2.5 \times 10^{4}$ cells ml $^{-1}$, a density which was of the same magnitude as in other microcosm studies with $V$. cholerae $[15,18]$. The flasks were sealed with a sterile cap and bubbled slightly with sterile filtered air. The cultures were incubated in the dark at different temperatures $\pm 1^{\circ} \mathrm{C}$ according to the in situ temperature at the respective sampling date (copepods: $10,15,20^{\circ} \mathrm{C}$; cladocerans: 20 , $23,25^{\circ} \mathrm{C}$ ) and sub-sampled at regular intervals of $6 \mathrm{~h}$ for a period of $66 \mathrm{~h}$. These temperature ranges were chosen because copepods are present throughout the year in the lake, while cladocerans dominate the plankton during the warm season. Additional experiments were performed at $25^{\circ} \mathrm{C}$ for both zooplankton species to rule out a possible temperature effect (see below: multi-strain experiments). Subsamples for enumeration of $V$. cholerae using Fluorescence In Situ Hybridization (FISH) $(20 \mathrm{ml})$ as well as for total bacterial numbers using acridine orange direct counting $(1 \mathrm{ml})$ were collected with sterile glass pipettes at each sampling time. Samples for FISH were fixed with $5 \mathrm{ml}$ of para-formaldeyhde (1\% final concentration) for $12 \mathrm{~h}$ at $4{ }^{\circ} \mathrm{C}$; samples for acridine orange direct count were fixed with $50 \mu 1$ formaldehyde ( $2 \%$ final concentration) for up to 3 days at $4^{\circ} \mathrm{C}$.

\section{Enumeration of $V$. cholerae Attached to Zooplankton}

In the beginning and at the end of all experiments, six to ten live A. spinosus or $D$. mongolianum individuals were collected from the growth cultures with sterile pipettes to test for associated $V$. cholerae non-O1/non-O139. The zooplankton was carefully rinsed with sterile filtered NSW. For enumeration using FISH, the animals were placed into $10 \mathrm{ml}$ PBS and fixed with $10 \mathrm{ml}$ paraformaldehyde (final concentration 1\%). After $6 \mathrm{~h}, 20 \mathrm{ml}$ of a tetrasodium-pyrophosphate solution $(0.05 \mathrm{M}$ final concentration) was added and shaken on ice for $6 \mathrm{~h}$. Samples were sonicated for $30 \mathrm{~s}$ at $40 \mathrm{~W}$ (Branson sonicator S250D) and filtered through a $56-\mu \mathrm{m}$ mesh sterile nylon net to remove large particles. In all three copepod experiments and in two cladoceran experiments $\left(20,25^{\circ} \mathrm{C}\right)$, more than $90 \%$ of the individuals were alive at the end of the experiments, only a few individuals were found dead at the bottom of the experimental flasks. In the cladoceran experiment carried out at $23^{\circ} \mathrm{C}$, fewer than $20 \%$ of all individuals survived, but this had no influence on the general trends as observed in the other experiments.

\section{Multi-strain Experiments}

To test for ecological variability of the relationship of $V$. cholerae and the two zooplankton species, we performed two experiments with five $V$. cholerae non-O1/non-O139 strains randomly selected from our lake Neusiedler See strain collection and one non-O1/non-O139 V. cholerae strain from the national Dutch strain collection (NCCB36033). The V. cholerae cells from pre-cultures were added to $400 \mathrm{ml}$ of $2-\mu \mathrm{m}$-filtered lake water ('with competition'), with and without 50 zooplankton individuals and monitored over $72 \mathrm{~h}$. A common temperature of $25^{\circ} \mathrm{C}$ was used in order to rule out that differences between the single strain experiments with copepods and the ones with cladocerans are attributed to the different temperatures used. Again, at the end of the experiments more than $90 \%$ of all copepod and cladoceran individuals were alive. 
Samples for $V$. cholerae and total cell number determination were taken and fixed as described above.

Fluorescence in Situ Hybridisation

Fixed samples were filtered on white polycarbonate membranes (ø $25 \mathrm{~mm}$, pore-size $0.2 \mu \mathrm{m}$, Whatman) and air-dried for about $1 \mathrm{~h}$. Dry filters were either used immediately or transferred into sterile $1.5-\mathrm{ml}$ Eppendorf tubes and stored at $-20^{\circ} \mathrm{C}$ until use. For hybridisation, a 6FAM-labelled probe, Vchomim1276 (5'-[6-FAM]-ACT TTG TGA GAT TCG CTC CAC CTC G-3') was used [19] at a working concentration of $50 \mathrm{ng} \mathrm{H}^{-1}$ in sterile water. $270 \mu 1$ hybridisation solution $(0.9 \mathrm{M} \mathrm{NaCl}, 20 \mathrm{mM}$ TRIS-HCl, $0.01 \%$ SDS, $35 \%$ formamide) was mixed with $30 \mu \mathrm{l}$ 6-FAM-labelled probe in a 0.7-ml Eppendorf tube. A quarter of each frozen filter was cut out with a scalpel and added to the hybridisation mix. Ten to 15 filter sections can be put into one $0.7-\mathrm{ml}$ Eppendorf tube. Hybridisation was performed at $46^{\circ} \mathrm{C}$ for $1.5 \mathrm{~h}$ [20]. Alternative to hybridisation on filters, cells can be concentrated by centrifugation and hybridised in poly-L-lysine coated multi-well slides [19], a procedure which may be advantageous for turbid samples. In that protocol, a 24-h-hybridisation period is necessary to make the target region accessible [21]. After hybridisation, the filter sections were transferred in $50-\mathrm{ml}$ pre-warmed washing buffer $(80 \mathrm{mM} \mathrm{NaCl}$, $20 \mathrm{mM}$ TRIS-HCl, $5 \mathrm{mM}$ EDTA, $0.01 \%$ SDS) and incubated for another $30 \mathrm{~min}$ at $48^{\circ} \mathrm{C}$. The washing buffer with filter sections was poured through a suction strainer, the filter sections were rinsed with ethanol (80-100\%) and air-dried on paper in the dark. For counterstaining, the filter was placed on top of a drop of DAPI mix (5.5 parts Citifluor [Groepl, Tulln, Austria], 1 part Vectashield [Vector Laboratories, Burlingame, CA], 0.5 parts $1 \times$ PBS, DAPI [Sigma-Aldrich, Vienna, Austria] final concentration $1 \mu \mathrm{g} \mathrm{ml}^{-1}$ ) on a microscope slide, covered with another drop DAPI mix, mounted with a cover slip and incubated for $10 \mathrm{~min}$ in the dark. Microscope slides can be stored at $-20^{\circ} \mathrm{C}$ for several months. Stained filters were examined under a Nikon Eclipse 8000 microscope at $\times 1,250$ magnification and at least 20 microscopic fields were counted for the enumeration of $V$. cholerae. For ruling out false positives, we tested a variety of related Vibrio species (V. fluvialis, V. alginolyticus, V. parahaemolyticus, V. vulnificus, $V$. fischeri) which were all negative for the probe. During summer 2008, the FISH probe was also applied for a series of environmental samples from the Lake Neusiedler See and compared to results from cultivation. There was no significant difference between the results from the two methods, indicating that the use of the FISH probe Vchomim 1276 does not overestimate Vibrio cholerae numbers (Kirschner, unpublished data).

\section{Growth Rate and Growth Yield}

From the increase in cell numbers, the specific growth rate $(\mu)$ was calculated using the formula $\mu=\left(\ln \mathrm{BN}_{1}-\ln \mathrm{BN}_{0}\right) \times$ $\left(\mathrm{T}_{1}-\mathrm{T}_{0}\right)^{-1}$, where $\mathrm{BN}_{0}$ and $\mathrm{BN}_{1}$ are the bacterial numbers at the beginning (time zero $\left[T_{0}\right]$ ) and at the end $\left(T_{1}\right)$ of the exponential growth phase, respectively. The yield (absolute increase in bacterial numbers) was calculated by subtracting $\mathrm{BN}_{0}$ from the maximal $\mathrm{BN}$.

\section{Acridine Orange Direct Count}

The fixed 1-ml subsamples were filtered through black polycarbonate $0.2-\mu \mathrm{m}$-pore-size filters (Whatman) and stained with acridine orange according to the method of Hobbie et al. [22]. Stained filters were examined for total bacterial numbers, as described above.

Statistical Analysis

SPSS 17.0 for Windows was used for all statistical calculations. Paired $T$ test and Mann-Whitney $U$ Test were applied for testing for significant differences between treatments.

\section{Results}

Zooplankton Development and Correlation of $V$. cholerae non-O1/non-O139 with Zooplankton and Temperature

During the period from 2001 to 2004, the concentration of the two dominant crustacean zooplankton species in the lake varied between 3 and $320 \mathrm{~L}^{-1}$ for the copepod, A. spinosus and 0 to $250 \mathrm{~L}^{-1}$ for the cladoceran, D. mongolianum (Supporting information: Fig. S2A). D. mongolianum development followed a typical seasonal pattern with significant increase in numbers during the warm months of May to September and showed significant correlation with temperature $(\mathrm{rho}=0.74$; $p<0.001 ; n=96)$. A. spinosus was also present in large numbers during the winter months, with no significant correlation with temperature $(r h o=0.15 ; p>0.1 ; n=96)$. The prevalence of culturable $V$. cholerae non-O1/non-O139, determined as percentage of $V$. cholerae non-O1/non-O139 positive samples, followed a typical seasonal pattern and was significantly correlated with temperature (rho $=0.65 ; p<0.001 ; n=$ 102; Supporting information: Fig. S2B). A significant correlation was found with $D$. mongolianum $(\mathrm{rho}=0.62 ; p<0.001 ; n=$ 94) but not with $A$. spinosus (rho $=0.13 ; p>0.2 ; n=94$ ).

Growth Experiments with Cladocerans

The addition of cladocerans to the microcosms significantly enhanced growth of $V$. cholerae non-O1/non- 
Table 1 Summary of growth experiments with cladocerans

\begin{tabular}{|c|c|c|c|c|c|c|c|}
\hline \multirow[t]{2}{*}{ Temperature } & \multirow[t]{2}{*}{ Treatment } & \multicolumn{3}{|c|}{ Without competition } & \multicolumn{3}{|c|}{ With competition } \\
\hline & & $\mu\left[\mathrm{h}^{-1}\right]$ & Yield & $p$ value & $\mu\left[\mathrm{h}^{-1}\right]$ & Yield & $p$ value \\
\hline \multirow[t]{3}{*}{$25^{\circ} \mathrm{C}$} & Control & 0.076 & $2.30 \times 10^{4}$ & - & 0.002 & $0.04 \times 10^{4}$ & - \\
\hline & 50 clad & 0.120 & $6.31 \times 10^{4}$ & $<0.01$ & 0.068 & $2.99 \times 10^{4}$ & $<0.01$ \\
\hline & $150 \mathrm{clad}$ & 0.176 & $21.3 \times 10^{4}$ & $<0.01$ & 0.166 & $14.9 \times 10^{4}$ & $<0.01$ \\
\hline \multirow[t]{3}{*}{$23^{\circ} \mathrm{C}$} & control & 0.095 & $4.39 \times 10^{4}$ & - & 0.025 & $0.82 \times 10^{4}$ & - \\
\hline & 50 clad & 0.184 & $20.0 \times 10^{4}$ & $<0.01$ & 0.088 & $11.3 \times 10^{4}$ & $<0.01$ \\
\hline & $150 \mathrm{clad}$ & 0.188 & $61.0 \times 10^{4}$ & $<0.01$ & 0.095 & $10.3 \times 10^{4}$ & $<0.01$ \\
\hline \multirow[t]{3}{*}{$20^{\circ} \mathrm{C}$} & Control & 0.128 & $10.8 \times 10^{4}$ & - & 0.106 & $13.8 \times 10^{4}$ & - \\
\hline & 50 clad & 0.134 & $69.8 \times 10^{4}$ & $<0.01$ & 0.137 & $105 \times 10^{4}$ & $<0.01$ \\
\hline & $150 \mathrm{clad}$ & 0.130 & $61.0 \times 10^{4}$ & $<0.01$ & 0.158 & $39.9 \times 10^{4}$ & $<0.01$ \\
\hline
\end{tabular}

Data indicate calculated growth rates $(\mu)$ and growth yield of $V$. cholerae non-O1/non-O139 without (control) and with (50 and 150$)$ added cladocerans (clad)

All experiments were performed 'with competition' (2- $\mu$ m filtered lake water) and 'without initial competition' (sterile filtered lake water) by the natural bacterial community

Each single $\mu$ and yield value is derived from one growth curve consisting of 12 consecutive sampling points

The $p$ value indicates the significance of the difference in cell numbers between control and the cultures with cladocerans (paired $T$ test; based on cell number data in logarithmic and stationary phase)

O139 in comparison to the respective controls (for growth rate: $p<0.001$; for growth yield: $p<0.001 ; n=$ 12 ; significance values calculated from pooled results in Table 1). A representative example of $V$. cholerae growth rates with two concentrations of cladocerans and in the respective control is shown in Fig. 1. After a short lag phase of 6 to $18 \mathrm{~h}, V$. cholerae non-O1/non-O139 increased markedly, to 1.5 orders of magnitude, in all batch cultures with cladocerans, while slower growth was observed in the controls. Also, in the sterile filtered cultures ('without initial competition'), a bacterial community, inoculated from the cladoceran surfaces, developed during the experiment to a final concentration of $3.5 \times 10^{6} \mathrm{ml}^{-1}$ (Fig. 1a, small insert). In the $2-\mu \mathrm{m}$ filtered lake water ('with competition') the natural bacterial community increased from $1 \times 10^{6}$ to $2.5 \times 10^{6}-4 \times 10^{6}$ cells $\mathrm{ml}^{-1}$ (Fig. 1b, small insert). Table 1 summarises results of all experiments. Based on cell number data from logarithmic and stationary phase, the differences between control and the cultures with cladocerans were in all experiments statistically significant. In the batch cultures at $25^{\circ} \mathrm{C}$ and $23^{\circ} \mathrm{C}$, without initial competition, $V$. cholerae non-O1/non-O139 growth rates $(\mu)$ approximately doubled in the presence of cladocerans compared to the control, and growth yield increased ten times to 14 times with cladocerans. At $20^{\circ} \mathrm{C}$, a similar growth rate and a significantly (six times) higher growth yield was observed with cladocerans. In all batch cultures with a competing natural bacterial community, cladocerans had a significant positive effect on $V$. cholerae non-O1/nonO139 growth. Growth rates were 1.5-83 times and growth yields 7.6-370 times higher in all batch cultures with cladocerans than in the controls. The presence of a competing natural bacterial community in the batch cultures had a significant negative effect on growth rate $(p<0.05 ; n=9)$ and growth yield $(p<0.01 ; n=9)$ of $V$. cholerae non-O1/nonO139, when comparing all values obtained from experiments 'without initial competition' with values obtained from experiments 'with competition'.

\section{Enumeration of $V$. cholerae Attached to Cladocerans}

V. cholerae non-O1/non-O139 associated with surfaces of cladocerans were determined in the beginning and at the end of each experiment. In the beginning, FISH-based cell numbers were between 0 and 340 cells per individual and increased to $30 \times 10^{4}$ to $77 \times 10^{4}\left(25^{\circ} \mathrm{C}\right), 0.2 \times 10^{4}$ to $4.5 \times$ $10^{4}\left(23^{\circ} \mathrm{C}\right)$ and $0.4 \times 10^{4}$ to $1.2 \times 10^{4}\left(20^{\circ} \mathrm{C}\right) \mathrm{V}$. cholerae non-O1/non-O139 per individual.

\section{Multi-strain Experiments - Cladocerans}

To test for the variability of the observed patterns among different $V$. cholerae strains, additional experiments, run at $25^{\circ} \mathrm{C}$, with five autochthonous $V$. cholerae non-O1/nonO139 strains from our strain collection and one 'foreign' $V$. cholerae non-O1/non-O139 strain (NCCB36033) were performed. All strains showed a higher growth rate and growth yield in the presence of cladocerans than in the control (Table 2). In comparison to the autochthonous $V$. cholerae non-O1/non-O139 strains, the 'foreign' $V$. cholerae strain grew slower and with lower growth yield. Also, the number 
Figure 1 Representative example $\left(25^{\circ} \mathrm{C}\right.$ experiment $)$ of the development of FISH-based $V$. cholerae non-O1/non-O139 concentrations in 800-ml microcosms amended with 0 (control), 50 and 150 cladocerans (Clad). a sterile filtered lake water ('without initial competition'); b 2- $\mu \mathrm{m}$ filtered lake water ('with competition'). Small inserts: development of the natural bacterial community (counted as total bacteria less $V$. cholerae nonO1/non-O139 cells) during the experiment. Error bars indicate the standard error of counts derived from 20 microscopic fields and are mostly smaller than the data point
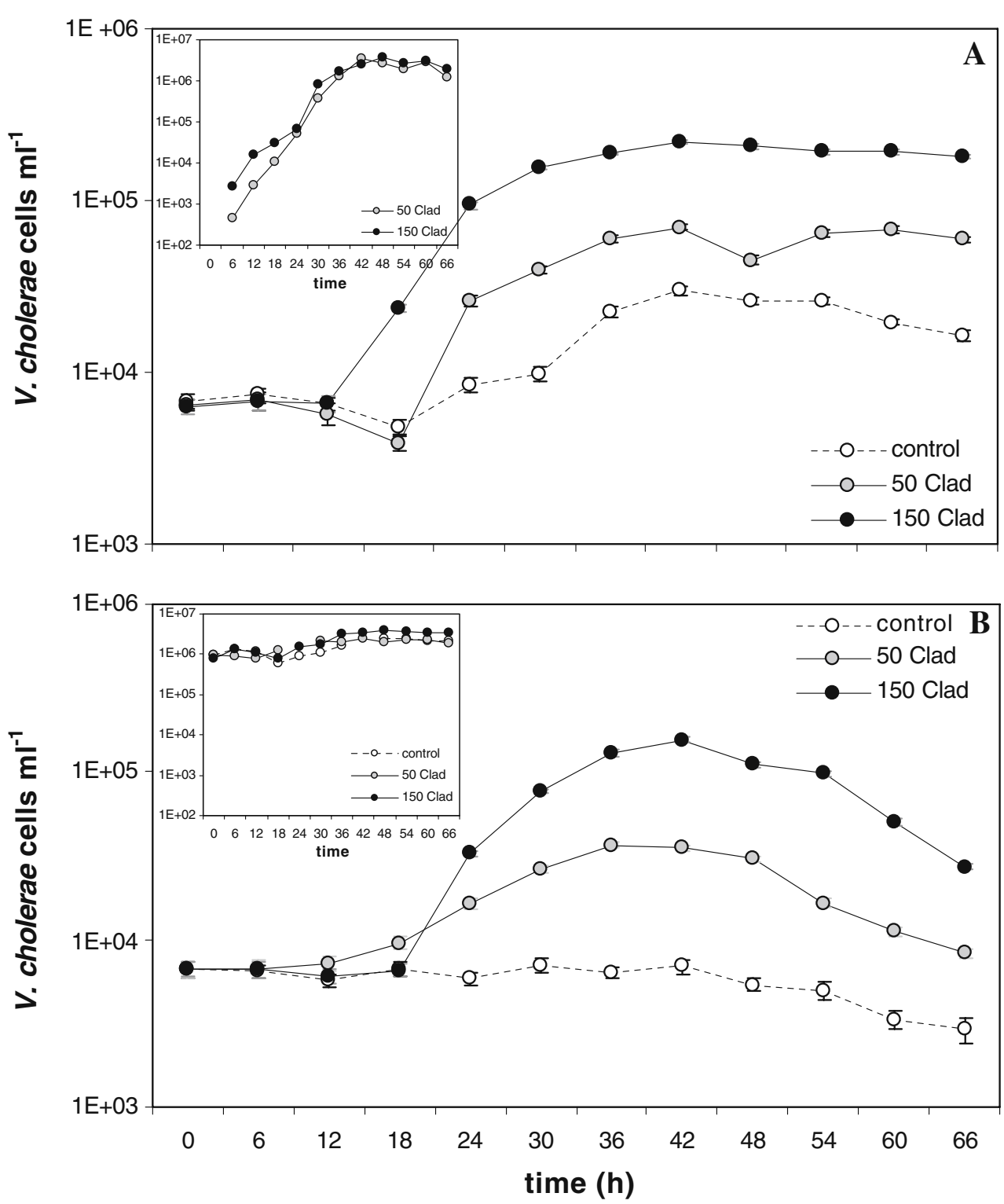

of $V$. cholerae attached to cladocerans was markedly lower than for the autochthonous strains.

\section{Growth Experiments with Copepods}

The addition of copepods had a significant negative impact on planktonic $V$. cholerae non-O1/non-O139 growth in comparison to the respective controls (for growth rate, $p<0.001$; and growth yield, $p<0.05 ; n=12$; significance values calculated from pooled results in Table 3). A representative example of FISH-based $V$. cholerae non-O1/non-O139 enumeration is shown in Fig. 2. In comparison to the control, growth rates and growth yield were lower in all batch cultures with copepods. In this experiment, the lowest growth and the largest difference compared with the control were found in the cultures with 50 and not with 150 copepods. As in the experiments with cladocerans, a competing bacterial community developed in the batch cultures with sterile filtered lake water ('without initial competition') due to the inoculation of bacteria from the copepod surfaces (Fig. 2a, small insert). Competing bacteria reached similar cell concentrations (approximately $2 \times 10^{6} \mathrm{cells} \mathrm{ml}^{-1}$ ) as in the cultures with 2- $\mu \mathrm{m}$ filtered lake water (Fig. 2b, small insert). Table 3 summarises the results of FISH-based $V$. cholerae non-O1/non-O139 enumerations of all experiments. Based on cell number data from logarithmic and stationary phase, the differences between control and the cultures with copepods were in all experiments statistically significant (exception $10^{\circ} \mathrm{C}$, with competition). Without initial competition, growth rates were 1.5 to 2 times and growth yield up to 32 times higher in the controls than in the batch cultures with copepods. With competition, the difference between controls 


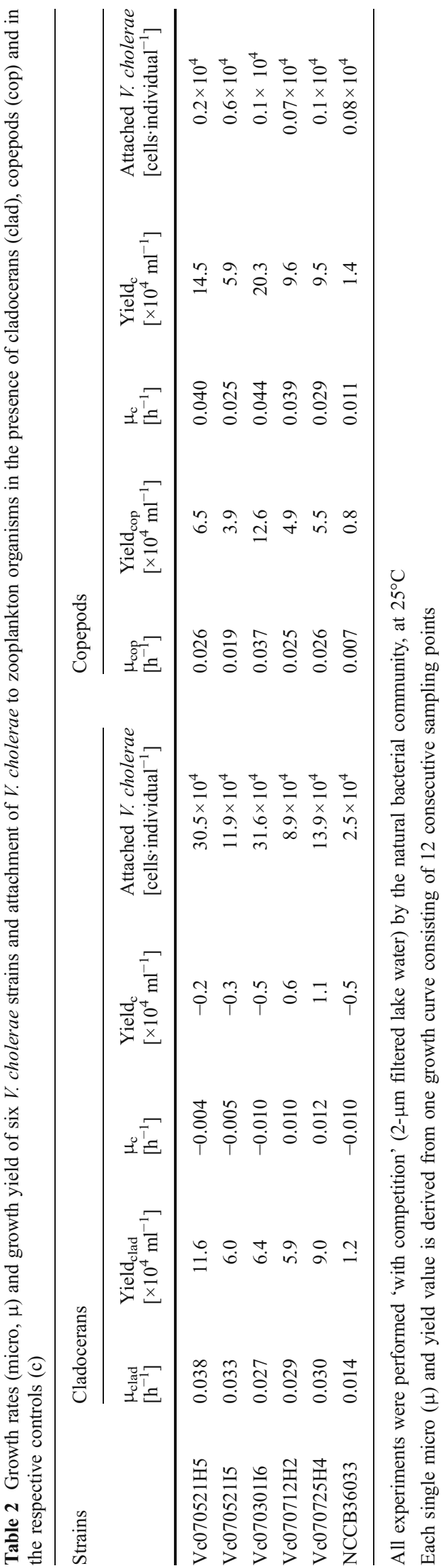

and copepod cultures was 1.2-1.6 times for growth rates and up to 13 times for growth yield. In the batch cultures run at $10^{\circ}$ $\mathrm{C}$, the differences between the treatments were negligible because of reduced $V$. cholerae non-O1/non-O139 growth rates due to the low temperature. The presence of competing bacteria had a significant negative impact on $V$. cholerae non-O1/non-O139 growth in all experiments (Table 3). On the one hand, this became obvious by direct comparison between batch cultures with and without initial competition. Growth rates of $V$. cholerae non-O1/non-O139 under competition were between 1.1 to 5 times $(p<0.001, n=9)$ and growth yields between 1.4 to 50 times lower $(p<0.001, n=9)$ than without initial competition. On the other hand, there was a significant negative correlation between the abundance of competing bacteria developing in the batch cultures with sterile filtered lake water and the difference of $V$. cholerae non-O1/non-O139 numbers between the control and cultures with copepods (Spearman's rank correlation coefficients ranging from -0.87 to $-0.94 ; p<0.001)$. This means that the higher the concentration of competing bacteria was, the lower the growth performance of $V$. cholerae non-O1/nonO139 irrespective of the number of copepods in the culture.

\section{Enumeration of $V$. cholerae Attached to Copepods}

V. cholerae non-O1/non-O139 associated with external surfaces of the copepods were determined in the beginning and at the end of each experiment. Cell numbers per individual copepod were significantly lower than for cladocerans. Cell numbers ranged from 0 to 100 cells per individual in the beginning and increased to $1 \times 10^{3}$ to $7 \times 10^{3}\left(20^{\circ} \mathrm{C}\right), 700$ to $1.3 \times 10^{3}\left(15^{\circ} \mathrm{C}\right)$ and 700 to $2.5 \times 10^{3}$ per individual $\left(10^{\circ} \mathrm{C}\right)$.

Multi-strain Experiments - Copepods

In additional experiments, run at $25^{\circ} \mathrm{C}$, with five autochthonous $V$. cholerae non $\mathrm{O} 1 /$ non-O139 and one "foreign" V. cholerae non-O1/non-O139 strain (NCCB36033), the presence of copepods had also a significant negative impact on $V$. cholerae growth rates and growth yields in all cases $(p<0.001, n=6)$. As observed in the multi-strain experiment with cladocerans, the 'foreign' $V$. cholerae strain had a much worse performance than the autochthonous strains (Table 2). The number of $V$. cholerae attached to copepods ranged from $7 \times 10^{2}$ to $6 \times 10^{3}$ cells per individual.

\section{Discussion}

Interaction with Zooplankton

The composition of the crustacean zooplankton as well as the presence of competing bacteria had a significant 
Table 3 Summary of growth experiments with copepods

\begin{tabular}{|c|c|c|c|c|c|c|c|}
\hline \multirow[t]{2}{*}{ Temperature } & \multirow[t]{2}{*}{ Treatment } & \multicolumn{3}{|c|}{ Without competition } & \multicolumn{3}{|c|}{ With competition } \\
\hline & & $\mu\left[\mathrm{h}^{-1}\right]$ & Yield & $p$ value & $\mu\left[\mathrm{h}^{-1}\right]$ & Yield & $p$ value \\
\hline \multirow[t]{3}{*}{$20^{\circ} \mathrm{C}$} & Control & 0.153 & $113 \times 10^{4}$ & - & 0.058 & $2.23 \times 10^{4}$ & - \\
\hline & 50 cop & 0.102 & $34.9 \times 10^{4}$ & $<0.01$ & 0.049 & $1.68 \times 10^{4}$ & $<0.01$ \\
\hline & 150 cop & 0.086 & $28.0 \times 10^{4}$ & $<0.01$ & 0.047 & $1.56 \times 10^{4}$ & $<0.01$ \\
\hline \multirow[t]{3}{*}{$15^{\circ} \mathrm{C}$} & Control & 0.146 & $250 \times 10^{4}$ & - & 0.101 & $71.4 \times 10^{4}$ & - \\
\hline & 50 cop & 0.091 & $7.78 \times 10^{4}$ & $<0.01$ & 0.081 & $5.47 \times 10^{4}$ & $<0.01$ \\
\hline & 150 cop & 0.076 & $41.6 \times 10^{4}$ & $<0.01$ & 0.060 & $12.1 \times 10^{4}$ & $<0.01$ \\
\hline \multirow[t]{3}{*}{$10^{\circ} \mathrm{C}$} & Control & 0.063 & $13.6 \times 10^{4}$ & - & 0.013 & $0.28 \times 10^{4}$ & - \\
\hline & 50 cop & 0.036 & $1.77 \times 10^{4}$ & $<0.01$ & 0.012 & $0.37 \times 10^{4}$ & n.s. \\
\hline & 150 cop & 0.038 & $0.77 \times 10^{4}$ & $<0.01$ & 0.009 & $0.36 \times 10^{4}$ & n.s. \\
\hline
\end{tabular}

Data indicate calculated growth rates $(\mu)$ and growth yields of $V$. cholerae non-O1/non-O139 without (control) and with (50 and 150$)$ added copepods (cop)

All experiments were performed 'with competition' (2- $\mu$ m filtered lake water) and 'without initial competition' (sterile filtered lake water) by the natural bacterial community

Each single $\mu$ and yield value is derived from one growth curve consisting of 12 consecutive sampling points

The $p$ value indicates the significance of the difference in cell numbers between control and the cultures with copepods (paired $T$ test; based on cell number data in logarithmic and stationary phase)

n.s. Not significant

influence on the growth performance of autochthonous $V$. cholerae non-O1/non-O139 strains in the lake Neusiedler See. The high correlation of $V$. cholerae non-O1/non-O139 prevalence with abundance of the cladoceran species $D$. mongolianum that dominates the zooplankton in the lake during the warm season (April-October), suggested a possible strong relationship between the two. Addition of D. mongolianum to laboratory microcosms in all experiments showed significant enhancement of growth of $V$. cholerae non-O1/non-O139 in the lake water. In contrast, the copepod A. spinosus, which is present in the lake throughout the year, did not show significant correlation with $V$. cholerae. In batch cultures, addition of copepods resulted in significant decrease in the growth of $V$. cholerae non-O1/non-O139 in lake water, compared to controls. With cell densities varying from $2 \times 10^{3}$ to $7.7 \times 10^{5}$ per individual, D. mongolianum was much more intensely (3-320 times; average, 100 times) colonised by $V$. cholerae non-O1/ non-O139 than A. spinosus, with cell densities ranging from $7 \times 10^{2}$ to $7 \times 10^{3}$ per individual. For the 'foreign' V. cholerae non-O1/non-O139 strain, growth performance was significantly worse and cell densities attached to zooplankton were $1.2 \times 10^{4}$ and $8 \times 10^{2}$ cells per cladoceran and copepod, respectively, lower than for the autochthonous strains. Numbers up to $7.1 \times 10^{3}$ were found for $V$. cholerae $-V$. mimicus organisms associated to the exoskeleton of calanoid copepods in Chesapeake Bay, which was judged to be a conservative estimate [19]. It has been demonstrated that $V$. cholerae $01 / 0139$ preferably attach to copepods (Eurytemora and Acartia spp.) in the estuarine and marine environment, reaching cell densities of up to $10^{5}$ cells per individual $[1,6]$. The association with zooplankton has been suggested as an important factor in transmission of human epidemic cholera. According to the results of this study, interaction between different $V$. cholerae serogroups with different zooplankton species seems to be significantly distinct. Most recently, it was shown that $V$. cholerae 01 strain consistently achieved higher abundances (7-20 times) than $V$. cholerae 0139 in colonising multiple life stages of copepods [8], and up to $3 \times$ $10^{4}$ cells per copepod were reported. In the lake Neusiedler See, autochthonous $V$. cholerae non-O1/non-O139-in contrast to $V$. cholerae 01 strains in the estuarine and marine environment-obviously show a preference for growth on cladocerans than on the local copepods. In addition, $V$. cholerae non-O1/non-O139 growth was also enhanced in the surrounding water in the presence of $D$. mongolianum. Several reasons may be responsible for these observations. Most likely, specific serogroups may have differences in their adhesion capacities. Chiavelli et al. [23] proposed that deficient colonisation by $V$. cholerae 0139 may be associated with specific exopolysaccharides that contribute to biofilm formation. Although exopolysaccharides may provide the ability to form biofilms, they may hinder initial cell attachment [8]. Alternatively, the outer surface properties of D. mongolianum may be more appropriate for colonisation by $V$. cholerae non-O1/non-O139, in general, but no information on this is available to date. From the colonised outer surfaces, the swarming cells may be released to the 
Figure 2 Representative example $\left(15^{\circ} \mathrm{C}\right.$ experiment $)$ of the development of FISH-based $V$. cholerae non-O1/non-O139 concentrations in 800-ml microcosms amended with 0 (control), 50 and 150 copepods $(\mathrm{Cop})$. a sterile filtered lake water ('without initial competition') b 2- $\mu \mathrm{m}$ filtered lake water ('with competition'). Small inserts: development of the natural bacterial community (counted as total bacteria less $V$. cholerae nonO1/non-O139 cells) during the experiment. Error bars indicate the standard error of counts derived from 20 microscopic fields and are mostly smaller than the data point
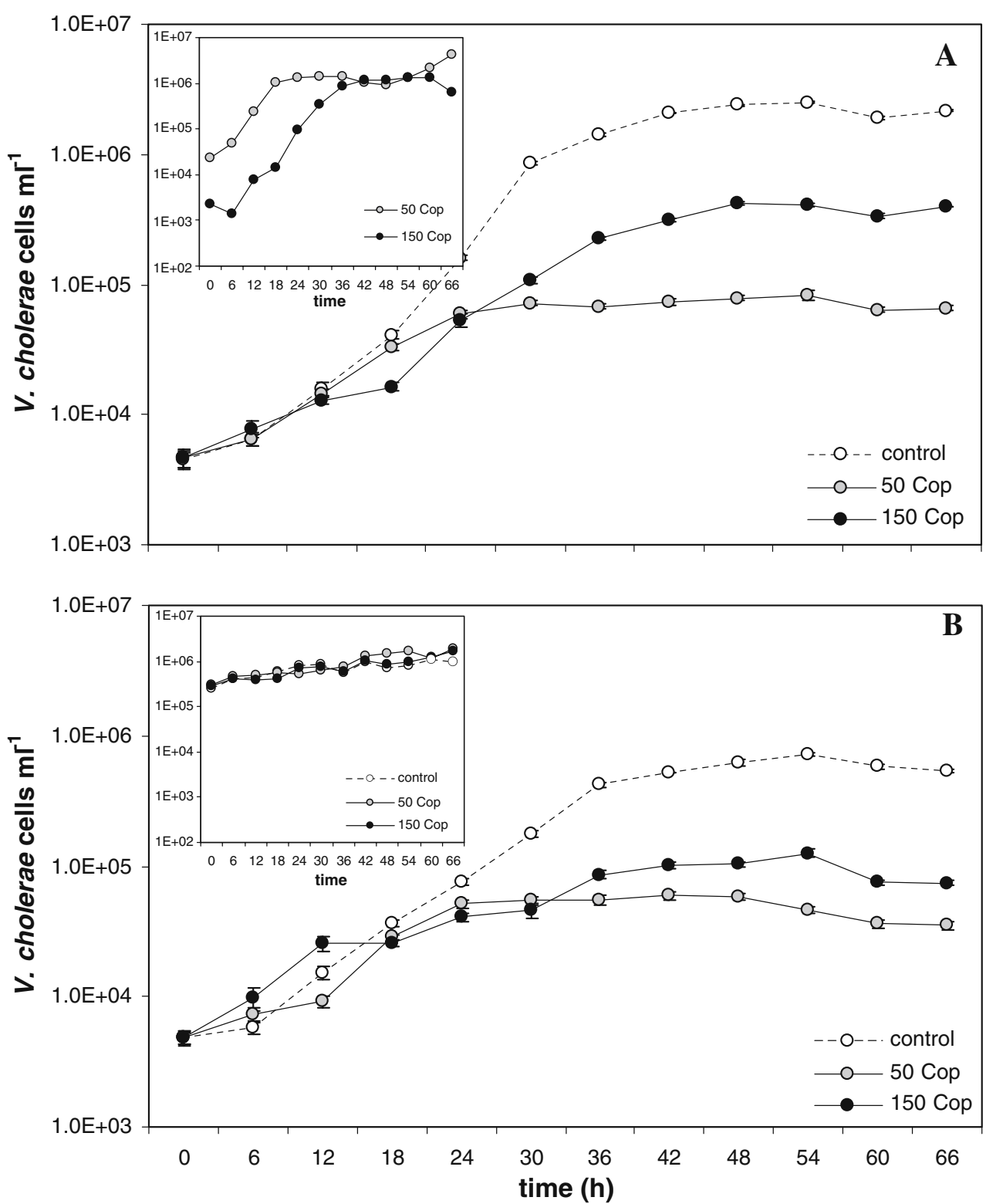

surrounding water, increasing the planktonic $V$. cholerae concentration. $V$. cholerae cells could also be released from inner surfaces of the gut where digestive by-products may enhance their growth. In the estuarine and marine environment crustacean zooplankton are hotspots for bacterial growth, as they concentrate organic matter in their guts and faecal pellets and provide attachment sites for bacterial colonisation [24, 25].

Influence of the Competing Natural Bacterial Community

The negative influence of $A$. spinosus on planktonic $V$. cholerae non-O1/non-O139 growth performance is most likely not due to grazing as grazing on particles in the size range of natural bacteria (diameter $0.2-1 \mu \mathrm{m}$ ) can be excluded for calanoid copepods like A. spinosus [26]. However, it was reported that copepods can selectively feed on large and active bacteria [27], as they may have occurred in the beginning of our experiments, when $V$. cholerae cells from pre-cultures were partly larger (maximum diameter approximately $1 \mu \mathrm{m}$ ) than at the end of the experiments. A direct negative influence of $A$. spinosus by grazing can thus not be completely ruled out. In our study, the natural bacterial community had exclusively a negative influence on $V$. cholerae non-O1/non-O139 growth performance and was thus considered to be 'competing bacteria'. In all experiments with competing bacteria, growth rates and growth yield of $V$. cholerae non-O1/non-O139 was significantly lower than in experiments with sterile filtered water. Moreover, a highly significant negative correlation was 
found between the concentration of competing bacteria and the difference in $V$. cholerae concentrations between cultures with and without copepods. This clearly indicates that bacterial populations inoculated into the sterile filtered water from the copepod surfaces reduced $V$. cholerae growth. Antagonistic interactions of marine bacteria impeding proliferation of $V$. cholerae have been reported to be based on the biosynthesis of andrimid, an antibacterial agent [28]. Also, the natural bacterial community may compete effectively with $V$. cholerae for readily assimilable organic matter, thereby lowering $V$. cholerae growth [15]. Most probably, both mechanisms interact in regulating $V$. cholerae proliferation on particles and in the water.

\section{Effect of Temperature}

The effect of temperature on $V$. cholerae non-O1/non-O139 growth was difficult to interpret. In the copepod experiments, as expected, $V$. cholerae growth was significantly lower at $10^{\circ} \mathrm{C}$ than at $15^{\circ}$ and $20^{\circ} \mathrm{C}$. In the presence of competing bacteria, very low net growth of $V$. cholerae non-O1/non-O139 was observed at $10^{\circ} \mathrm{C}$. In the cladoceran experiments, $V$. cholerae non-O1/non-O139 growth did not significantly increase with increasing temperature. Because the microcosms were designed to be as close to natural conditions as possible, fluctuations in available dissolved organic matter or in the competitiveness of the natural bacterial community may mask the temperature effect. But irrespective of all this variation, the outcome of the experiments, namely that the presence of cladocerans led to an increase and the presence of copepods led to a decrease of $V$. cholerae growth was always the same.

\section{Appropriateness of FISH-Based Quantification}

of $V$. cholerae

Our experiments demonstrated that the FISH protocol is highly appropriate for monitoring growth of $V$. cholerae in batch cultures. For this type of experiment, collecting cells on filters and hybridising under rotation in an Eppendorf tube, significantly reduced the duration of the assay, compared to the original protocol where cells are collected by centrifugation and hybridised on multi-well slides [19]. FISH, in our opinion, is superior to green fluorescent protein (GFP)-labelled cells [18] for such kind of growth experiments in the presence of competitive bacteria, as it is known that GFP-cells may have lower fitness and thus bias environmental behaviour, compared to wild-type strains [29]. Moreover, we have observed in preliminary experiments that using GFP-tagged autochthonous $V$. cholerae non-O1/non-O139 strains resulted in massive loss of GFP into the surrounding water during growth experiments. The cells were then surrounded by a green matrix and less visible by fluorescence microscopy, and thus also potentially less competitive.

In summary, the results of our studies clearly demonstrate a significant positive relationship of $V$. cholerae nonO1/non-O139 with the dominant cladocerans in the lake. The presence of $D$. mongolianum significantly enhanced $V$. cholerae non-O1/non-O139 growth in the surrounding water, as well as on external or internal surfaces of the cladocerans. In contrast, copepods (A. spinosus) were on average 100 times less colonised than cladocerans. The bacterial community inoculated from the copepods surfaces into the microcosms had a negative effect on $V$. cholerae non-O1/non-O139 growth most probably because of competition for nutrients. Thus, $V$. cholerae biofilm formation on crustacean zooplankton is zooplankton taxon specific and may be controlled, in addition to grazing pressure from planktonic protozoa [9], also by the natural bacterial community.

Acknowledgements The study was financed by the Province of Burgenland via the Arbeitsgemeinschaft Natürliche Ressourcen (AGN), and by the Austrian Science Fund (FWF, project nr: P21625-B20). Special thanks to Rudolf Schalli and Richard Haider for taking samples at Neusiedler See, as well as to L. Safak Yilmaz and Daniel R. Noguera (Department of Civil and Environmental Engineering, University of Wisconsin, Madison) for trouble-shooting during the development of the FISH protocol.

Open Access This article is distributed under the terms of the Creative Commons Attribution Noncommercial License which permits any noncommercial use, distribution, and reproduction in any medium, provided the original author(s) and source are credited.

\section{References}

1. Colwell RR, Kaper JB, Joseph SW (1977) Vibrio cholerae, Vibrio parahaemolyticus and other Vibrios: occurrence and distribution in Chesapeake Bay. Science 198:394-396

2. Colwell RR, Spira WM (1992) The ecology of Vibrio cholerae. In: Barua D, Greenough WB (eds) Cholera, 3rd edn. Plenum Medical Book co, New York, pp 107-127

3. Colwell RR (1996) Global climate and infectious disease: the cholera paradigm. Science 274:2025-2031

4. Cheasty T, Said B, Threlfall EJ (1999) Vibrio cholerae non-O1: implications for man? The Lancet 354:89-90

5. Morris JG (1990) Non 01 Vibrio cholerae: a look at the epidemiology of an occasional pathogen. Epidemiol Rev 12:179-191

6. De Magny GC, Murtugude R, Sapiano MRP, Nizam A, Brown $\mathrm{CW}$, Busalacchi AJ et al (2008) Environmental signatures associated with cholera epidemics. Proc Nat Acad Sci 105:17676-17681

7. Huq A, Small EB, West PA, Huq MI, Rahman R, Colwell RR (1983) Ecological relationships between Vibrio cholerae and planktonic crustacean copepods. Appl Environ Microbiol 45:275-283

8. Rawlings TK, Ruiz GM, Colwell RR (2007) Association of Vibrio cholerae $01 \mathrm{El}$ Tor and 0139 Bengal with copepods Acartia tonsa and Eurytemora affinis. Appl Environ Microbiol 73:7926-7933 
9. Matz C, McDougald D, Moreno AM, Yung PY, Yildiz FH, Kjelleberg S (2005) Biofilm formation and phenotypic variation enhance predation driven persistence of Vibrio cholerae. Proc Nat Acad Sci 102:16819-16824

10. Nalin DR (1976) Cholera, copepods and chitin. The Lancet 7992:958

11. Pruzzo C, Vezzulli L, Colwell RR (2008) Global impact of Vibrio cholerae interactions with chitin. Environ Microbiol 10:1400-1410

12. Bartlett DH, Azam F (2005) Chitin, cholera and competence. Science 310:1775-1777

13. Meiboom KL, Blokesch M, Dolganov NA, Wu CY, Schoolnik GK (2005) Chitin induces natural competence in Vibrio cholerae. Science 310:1824-1827

14. Huhulescu S, Indra A, Stoeger A, Ruppitsch W, Sarkar B, Allerberger F (2007) Occurrence of Vibrio cholerae serogroups other than 01 and 0139 in Austria. Wiener Klin Wochenschr 119:235-241

15. Kirschner AKT, Schlesinger J, Farnleitner AH, Hornek R, Süß B, Golda B, Herzig A, Reitner B (2008) Rapid growth of planktonic Vibrio cholerae Non-O1/Non-O139 strains in a large alkaline lake in Austria: dependence on temperature and dissolved organic carbon quality. Appl Environ Microbiol 74:2004-2015

16. Löffler H (1979) Neusiedler See: the limnology of a shallow lake in central Europe. Dr. W. Junk Publishers, The Hague

17. Krammer M, Velimirov B, Fischer U, Farnleitner AH, Herzig A, Kirschner AKT (2008) Growth response of soda lake bacterial communities to simulated rainfall. Microb Ecol 55:194-211

18. Worden AZ, Seidel M, Smriga S, Wick A, Malfatti F, Bartlett D, Azam F (2006) Trophic regulation of Vibrio cholerae in coastal marine waters. Environ Microbiol 8:21-29

19. Heidelberg JF, Heidelberg KB, Colwell RR (2002) Bacteria of the gamma-subclass Proteobacteria associated with zooplankton in Chesapeake Bay. Appl Environ Microbiol 68:5498-5507
20. Wilhartitz I, Mach RL, Teira E, Reinthaler T, Herndl GJ, Farnleitner AH (2007) Prokaryotic community analysis with CARD-FISH in comparison with FISH in ultra-oligotrophic ground- and drinking water. J Appl Microbiol 103:871-881

21. Yilmaz LS, Okten HE, Noguera DR (2006) Making all parts of the $16 \mathrm{~S}$ rRNA of Escherichia coli accessible in situ to single DNA oligonucleotides. Appl Environ Microbiol 72:733-744

22. Hobbie JE, Daley EJ, Jasper S (1977) Use of nuclepore filters for counting bacteria by fluorescence microscopy. Appl Environ Microbiol 33:1225-1228

23. Chiavelli DA, Marsh JW, Taylor RK (2001) The mannose sensitive hemagglutinin of Vibrio cholerae promotes the adherence to zooplankton. Appl Environ Microbiol 67:3220-3225

24. Möller EF, Riemann L, Söndergaard M (2007) Bacteria associated with copepods: abundance, activity and community composition. Aquat Microb Ecol 47:99-106

25. Tang KW (2005) Copepods as microbial hot spots in the ocean: effects of host feeding activities on attached bacteria. Aquat Microb Ecol 38:31-40

26. DeMott WR (1988) Discrimination between algae and artificial particles by freshwater and marine copepods. Limnol Oceanogr 33:397-408

27. Bertilsson S, Hansson LA, Graneli W, Philibert A (2003) Size selective predation on pelagic microorganisms in Arctic freshwaters. J Plankton Res 25:621-631

28. Long RA, Rowley DC, Zamora E, Liu J, Bartlett DH, Azam F (2005) Antagonistic interactions among marine bacteria impede the proliferation of Vibrio cholerae. Appl Environ Microbiol 71:8531-8536

29. Allison DG, Sattenstall MA (2007) The influence of green fluorescent protein incorporation on bacterial physiology: a note of caution. J Appl Microbiol 103:318-324 